\title{
Leadership Style Analysis PT. Bangun Persada Regatama During the Covid-19 Pandemic
}

\author{
Widya Rahayua), and Komang Satria Wibawa Putra \\ Program Study IImu Komunikasi, Universitas Pendidikan Nasional, Denpasar, Indonesia \\ Corresponding Author: ${ }^{a}$ widya.rahayu020@gmail.com
}

\begin{abstract}
To break the chain of spread of the Covid-19 virus, the government issued a PPKM policy which requires essential companies to only employ $25 \%$ of their employees, this has resulted in the company experiencing an unexpected crisis. the readiness of a company's leadership to determine thelevel of effectiveness in dealing with the onslaught of the Covid-19 pandemic. This analysis focuseson the leadership style in the company PT. BPR in dealing with the Covid-19 outbreak by examiningthe level of alertness, responsiveness, cohesiveness, and coordination between organizations. The results of the study show that leaders at PT BPR use an empathetic leadership style which is one of the choices for leaders to carry out leadership functions during the covid-19 pandemic. One of RensisLikert's theories is 4 Systems or 4 Leadership communication styles. A leader must have the attitudeof a Consultative Leader, meaning that with the current covid-19 pandemic, the leader should have little trust in his subordinates, subordinates need information, ideas or opinions through consultation.Because applying an empathetic leadership style alone is not enough to maintain the company and only reduces employee performance because it is considered that leaders provide opportunities and employees will be in a comfort zone.
\end{abstract}

Keywords: Covid-19 Pandemic, Leadership Style, PT BPR

\section{INTRODUCTION}

A pandemic is a condition of the spread of certain types of epidemics or diseases that occur in morethan one country. This epidemic is known as the Covid-19 Virus which has spread to almost all parts of the world. The pandemic condition has an impact on a situation that is out of control. The spread of Coronavirus Disease 2019 (COVID-19) exceeds the capacity of the epidemic. This makes the status of the spread of COVID-19 a pandemic outbreak (Dai, 2020).

The Covid-19 pandemic and the current government policy of implementing PPKM have resulted in a crisis that the majority of business leaders in the world never expected. With the PPKM policy which requires essential companies to only employ $25 \%$ of their employees. This policy requires leaders to employ WFH (Work Form Home) employees and manage company strategies so that the company can continue to run during the COVID-19 pandemic. For this reason, the Company Leader of PT BPR has a high responsibilityin leading the company to get out of the crisis. An effective way to be able to adapt to the current pandemic conditions so that companies able to survive in the midst of the crisis due to the Covid-19 pandemic, namely by creating a culture strong and relevant organization (Apriyanto \& Satrio, 2015).

While exercising the authority, the leadership seeks the participation of the employees with all their dedication and sense of ownership through the power of mobilization, motivation and communication in the organization (Khan \& Nawaz, 2016). Leadership or leadership is essentially accountability. According to (Bahrum \& Sinaga, 2015), the opinion is that leaders play an important role in carrying out their roles and duties in the organization. According to (Suherman, 2019), a leader who is assertive, alert, and critical can influence members to achieve the organization's vision and mission.

The author has made a visit to a company called PT Bangun Persada Regatama which is located at Mampang Square B/2, Jl. Mampang Prpt. Raya No.88, RT.4/RW.6, Tegal Parang, Kec. Mampang Prpt., South Jakarta City, Special Capital Region of Jakarta (Post Code 12790). This company applies an empathetic leadership style in running its organization during the covid-19 pandemic, while this leadership style can have a negative impact if there are no sanctions, especially WFH employees who cannot focus on the company. This is obtained by conducting 
comparative studies between the work process in the field (companies) and universities, thereby adding insight and experience in leading the company.

\section{METHOD}

Researchers used qualitative methods with data collection techniques of observation, interviews, anddocumentation. Researchers conducted interviews with the president director of PT. Bangun Persada Regatama Muhammad Yusran had several problems caused by the covid19 pandemic, which caused the company to experience a crisis and the PPKM policy that required essential companies to only employ $25 \%$ of their employees. With this policy, leaders must employ WFH (Work Form Home) employees and managecompany strategies so that the company can continue to run during the COVID-19 pandemic.

\section{RESULTS}

After analyzing the problems regarding the leadership style in the company PT. BPR, namely, usingan empathetic leadership style which is one of the choices for leaders to carry out their leadership functions. However, this is not effective and will not last long if the COVID-19 pandemic does not end. Because applying an empathetic leadership style will result in a lack of productivity at work, not only that, this will have an impact on solidity, communication within the organization is reduced because online discussions cannot detect whether employees are focused or not running the company.

According to Wahjosumidjo in (Fitriani, 2013), every leader's behavior in the decision- making process and problem solving is in accordance with the leadership style. Consultative Leadership Style, characterized by:

1. Decision making and problem solving carried out by the leader after listening to complaints

from subordinates.

2. The leader determines goals and puts forward various general provisions after going through

a process of discussion and consultation with subordinates.

3. Rewards and punishments are given to subordinates in order to motivate subordinates.

4. Good relations with subordinates.

According to (Fitriani, 2013), the consulting leadership style has one-sided direction and decision- making from the leader, but can create two-way communication and support for feedback from the workforce,such as ideas, suggestions, and criticism. Leadership style is often considered capable of influencing employeeperformance because of its balanced nature, so the potential for influence exerted by this leadership style on performance is generally greater than other leadership styles.

At the company PT Bangun Persada Regatama the leader has full rights over the company, both in theemployee recruitment process, tasks that must be done, as well as company finances must use the contract andsignature of the leader. At PT BPR the leader requires employees to remain professional in doing their work even though it is done at home or Work Form Home (WFH). In the company the leader provides an opportunityfor employees to provide opinions on strategies to advance the business, even though not all employee opinions are implemented by leaders.

Company leaders must have a firm nature in making decisions that have been made. Leaders continueto reward employees even during the pandemic if the turnover is in line with the target. Leaders provide rewards that are used to motivate subordinates rather than threats of punishment.

\section{DISCUSSION}

Leadership style can be misinterpreted as the ability of a leader to regulate or exercise his power, sothat it will lead to conditions in which many companies are over-regulated and underled, too many orders and lack of social control, and too little motivation, and creativity so that in the end failed. Therefore, the decision to apply the appropriate leadership style is something important and difficult (Karyawan et al., 2012)says that, a leader must apply leadership to manage his subordinates, because a leader will affect the successof the company in achieving its goals. The leader must hear the ideas and suggestions of the subordinates before making a decision. 
The leadership style of the company in the current difficult situation, which is required to maintain the morale of subordinates to remain positive, in addition to the need for a supportive leader and understanding of the conditions of subordinates who do not have a special spot to work comfortably at home. According to(Sutisna, 2020), empathetic leadership can also be one of the choices for leaders to carry out their functions as leaders. And at this time the policies that have been set during the pandemic, namely physical distancing and PSBB have the consequence of having to work at home or work from home (WFH) for all workers in Indonesia. So for that, there are many tips or motivations on how to stay productive with WFH that can be conveyed through writing, online seminars. Most of the motivation given comes from the employee's point of view. This WFH remains productive for workers at PT. Bangun Persada Regatama. Further understanding of the theory of empathy applied in the leadership process cannot be separated from the explanation of variousapproaches. There are two approaches used to understand the theory of empathy. Baron-Cohen \& Wheelwright cited by Fauziah, argues that the empathic leadership style can be divided into two approaches, namely the affective approach and the cognitive approach.

The affective approach is empathy as an emotional observation that responds to the affective of others. In the affective view, the difference is empathy that can be seen from how big and small the observer's emotional response to the emotions that occur in other people. The cognitive approach is the aspect that resultsin understanding the feelings of others. As well as the most basic in the process of empathy is the understanding of differences between individuals and others.

\section{CONCLUSIONS AND RECOMMENDATIONS}

Based on the results of the analysis and discussion of the leadership style of PT. Bangun Persada Regatama during the covid-19 pandemic, the author can conclude that, PT Bangun Persada Regatama Group is led by the founder of the company as well as the Main Director, namely Capt. Muhammad Yusran in leading the company has skills such as communication, public speaking, critical thinking and other supporting abilities. Based on the results of the analysis, the empathic leadership style as an ability to understand the needs of others, which means correctly understanding the feelings and thoughts of others can have a negative effect on employee performance productivity. The solution to the problems above can be balanced by addingone of the popular and widely applied leadership communication theories, namely the Rensis Likert 4 Systemtheory or 4 Leadership communication styles. One of them is a leadership style with a consultative system.

It is recommended to apply leadership training, especially at PT. Bangun Persada Regatama Group, should maintain or further develop the leadership style that has been applied during the covid-19 pandemic. to increase motivation for employees who are working from home or who work directly so that work remains productive.

\section{ACKNOWLEDGMENTS}

We thank God for the presence of Allah Subhanahu Wa Ta'ala, because of His blessings and grace, the researcher was able to complete the research. Community service can run smoothly. This community service can be carried out properly with the support of (1) Prof. Dr. I Nyoman Sri Subawa, S.T., S.Sos.,M.M.,IPM. As the Chancellor of the Universitas Pendidikan Nasional (2) Ir. I Wayan Sutama, M.T., IPM. As Head of Institute For Research and Community Service at the Universitas Pendidikan Nasional (3) Nuning Indah Pratiwi S.Sos., M.I.Kom as head of the Communication Science study program at the Universitas PendidikanNasional (4) Komang Satria Wibawa Putra, SH., MH. As supervisor of PKL Universitas Pendidikan Nasional

(5) Capt. Muhammad Yusran. As the President Director of PT. BPR, (5) Fadil Yunis. As Assistant to the President Director. May Allah Subhanahu Wa Ta'ala reward you with the kindness you deserve. Amin. 


\section{REFERENCES}

Apriyanto, W., \& Satrio, R. B. (2015). Pengaruh Gaya Kepemimpinan Transformasional Dan Motivasi Kerja Terhadap Kinerja Karyawan. Sekolah Tinggi IImu Ekonomi Indonesia (STIESIA) Surabaya,4(November).

Bahrum, S., \& Sinaga, I. W. (2015). PENGARUH KEPEMIMPINAN DAN MOTIVASI KERJA

TERHADAP KINERJA PEGAWAI ( Studi Pada Pegawai Lembaga Dewan Kawasan Perdagangan Bebas Pelabuhan Bebas Batam Bintan Karimun ) Batam State Polytechnics Program Studi Administrasi Bisnis Terapan Politeknik Negeri Bata. Jurnal Akuntansi, Ekonomi Dan Manajemen Bisnis, 3(2), 135-141.

Dai, N. F. (2020). Stigma Masyarakat Terhadap Pandemi Covid-19. Prosiding Nasional Covid-19, 66-73. covid19/article/download/47/32

Fitriani. (2013). Pengaruh Gaya Kepemimpinan Partisipatif Terhadap Kinerja Pegawai Pada Dinas Pendidikan Provinsi Kalimantan Timur. EJournal Administrasi Negara, 1(3), 989-1002.

Karyawan, K., Cipta, P. T., \& Semesta, N. (2012). Pengaruh Kepemimpinan Dan Motivasi Terhadap Kinerja Karyawan. Management Analysis Journal, 1(1), 1-13. https://doi.org/10.15294/maj.v1i1.503

Khan, \& Nawaz, A. (2016). The Leadership Styles And The Employees Performance: A Review. GomalUniversity Journal of Research [GUJR], 32(2), 144-150.

Suherman, S. (2019). Pengaruh Struktur Aset, Likuiditas, dan Profitabilitas terhadap Struktur Modal yangDimoderasi Oleh Ukuran Perusahaan. Mix: Jurnal Ilmiah Manajemen, 9(2), 369. https://doi.org/10.22441/mix.2019.v9i2.009

Sutisna, I. F. (2020). Gaya kepemimpinan dalam mendukung perilaku organisasi di PT. Kerry Ingredients Indonesia pada masa pandemi covid-19. Jurnal PROFIT Kajian Pendidikan Ekonomi Dan IImu Ekonomi, 7(2), 158-166. https://doi.org/10.36706/jp.v7i2.12904 


\section{APPENDIX}

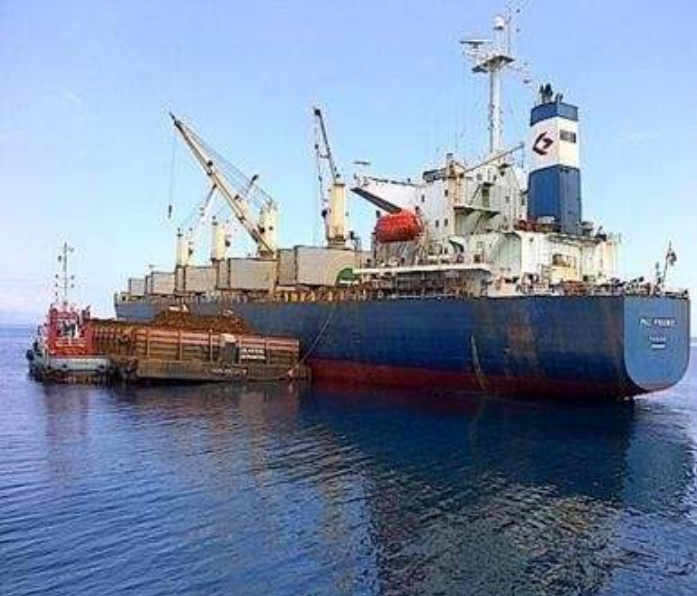

Figure 1. Fleet PT. Bangun Persada Regatama

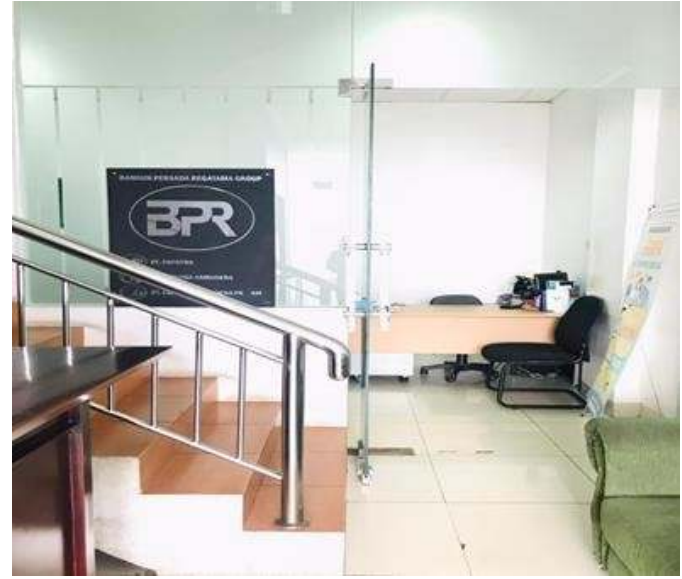

Figure 2. Office PT. Bangun Persada Regatama 